\title{
Waste Management in the Age of Alternative Energy
}

\author{
Yoojung Jo, Injae Yu, Saehyung Sohn, and Donyun Kim
}

\begin{abstract}
It is crucial to minimize the amount of urban waste causing many environmental problems. However, for getting rid of waste generated in the city life completely is impossible, the effort to utilize such waste as energy sources is increasing through the proper management. Despite the advantages and importance of waste management, Nimby makes it difficult to locate the facility in urban environment. The aim of this study is to draw a suitable direction for Korea's waste management to convert waste into energy. For this, investigated and analyzed were the international cases related to energy recovery from waste methods. As a result, there are common features: production of energy to replace fossil energy, high profitability, energy independence and the resolving of Nimby. Although local conditions and the situation in the foreign country may be different, perceptions and the role of principals who practice it need benchmarking for its own country's situation.
\end{abstract}

Index Terms-Alternative energy, waste management, Nimby phenomenon, climate change.

\section{INTRODUCTION}

\section{A. Background and Purpose}

Climate change is a global issue, and cities have been pointed out as the primary cause of climate change [1]. In particular, greenhouse gas emission in the city is a direct cause of the climate change by accelerating global warming. Greenhouse gas emission in the city is mainly caused by fossil fuels used in industries, transportations, and buildings [2]. It is important to reduce the use of fossil fuels in order to reduce the greenhouse gas in the city. Therefore, many studies on energy to replace fossil energy for this purpose are in progress, as well as on a variety of methods for using renewable energy.

It is crucial to minimize the amount of urban waste causing many environmental problems. However, for getting rid of waste generated in the city life completely is impossible, the effort to utilize such waste as energy sources is increasing through the proper management. Especially as population increases [3] and lifestyle changes, the problem regarding the

Manuscript received December 31, 2014; revised May 4, 2015. This work is financially supported by Korea Minister of Ministry of Land, Infrastructure and Transport(MOLIT) as "U-City Manpower Development Program". And this study is funded by Ministry of Land, Infrastructure and Transport of Korean Government which conducts the core based technology development project for advancing U-City (Code 13AUDP-B070066-03).

Yoojung Jo and Injae Yu are with Future City Convergence Engineering Department, Sung Kyun Kwan University, 440-746, 2066, Seobu-Ro, Jangan-Gu, Suwon, Gyeonggi-Do, Korea (e-mail: hcyoojung@gmail.com, injaeyoo@naver.com).

Saehyung Sohn is with the Architecture Department, Sung Kyun Kwan University, 440-746, 2066, Seobu-Ro, Jangan-Gu, Suwon, Gyeonggi-Do, Korea (e-mail: sohn6969@gmail.com).

Donyun Kim is with the Future City Convergence Engineering Department, Architecture Department, Sung Kyun Kwan University, 440-746, 2066, Seobu-Ro, Jangan-Gu, Suwon, Gyeonggi-Do, Korea (e-mail dnkim@skku.ac.kr). waste is urgent in the environment and health. Above all, it is a serious problem in developing country [4]. However, opportunities to recycle the waste have been gradually increasing because of the recent growth of the solid waste market, and the intense depletion of natural resources.

Energy recovery from waste can help minimize environmental pollution caused by the landfill of waste and make the most use of land. In addition, waste can be used as an energy source to replace fossil fuels, and it will eventually become a proactive way to climate change response. Also, energizing the waste will have the effects of the economic benefits associated with the creation of social value rises in the city along the way. However, despite the advantages and importance of waste management in the city, Nimby (Not in my back yard) phenomenon makes it difficult to locate the waste disposal facility in urban environment.

Nimby for environment facility is a universal phenomenon that appears in all cities rather than being limited to a particular city, or a country. Many cities have made various attempts to overcome Nimby not only in Korea also in developed countries overseas. And there are many successful cases as a result of the effort. We need to look closely into them as an example of waste management. This study aims to draw a suitable direction for Korea's waste management to convert waste into energy.

\section{B. Methodology}

Energy recovery from waste method is largely divided into anaerobic digestion, incineration, and special heat treatment [4], [5]. Anaerobic digestion means to produce biogas with an organic waste treatment, while incineration is a method of heat treatment of the solid waste in most common cities. For special heat treatment process, there are pyrolysis and gasification technologies and construction methods, but due to lack of economic advantage, it is not widely commercially available. Biogas has almost no impact on climate change, unlike fossil fuels, hence it is the core of resolving future energy problems; anaerobic digestion to produce biogas is a suitable method for the high water content of the organic waste.

Incineration of the waste - when the water is heated by the gas discharged from the thermal process - generates steam, and this steam could be used to operate turbine to produce electricity or heat, making incineration a general heat treatment method.

In this study, selected, investigated and analyzed are the international cases related to anaerobic digestion and incineration of energy recovery from waste methods. Related cases are selected for anaerobic digestion and incineration respectively; Austria Mureck, Guissing and Germany Juehnde for anaerobic digestion cases, and Austria Spittelau incineration plant, Japan Maishima incineration plant for incineration cases (see Table I). The cases in each category 
will be looked at and compared with Korean status to derive implications.

TABLE I: SELECTED CASES OF WASTE MANAGEMENT

\begin{tabular}{c|c|l|l|l|l}
\multicolumn{2}{c}{ TABLE I: SELECTED CASES OF WASTE MANAGEMENT } \\
\hline \hline & \multicolumn{2}{|c}{ Anaerobic Digestion } & \multicolumn{2}{c}{ Incineration } \\
\hline Case & Mureck & Guissing & Juehnde & $\begin{array}{l}\text { Spittelau } \\
\text { incineration } \\
\text { plant }\end{array}$ & $\begin{array}{l}\text { Maishima } \\
\text { incineration } \\
\text { plant }\end{array}$ \\
\hline
\end{tabular}

\section{WASTE MANAGEMENT}

UK government is promoting Eco-town Project that would offer a higher level of sustainable living than the existing urban cities, and making an effort to create a low-carbon town on a trial basis. Eco-Town is a integrated design guideline that would help stimulate Water Management, Inclusive Design, Waste Management and Policy Discussions. The waste management [6] must be managed sustainably to ensure that all waste and recycling should be managed in everyday life. The waste storage facility must be installed to allow separate collection of waste, and it must be considered if household waste could be used in co-generation. The landfill or incineration of waste should not end in itself, but explore different ways of using wasted heat generated by incineration.

So far, the waste management landfill or incineration been accounted for most ratios in waste management, but the best way is to reduce the amount itself. It must lead to minimization of the waste's impact on climate change. United Nations has already set and deployed the waste management hierarchy [4] to worldwide (see Fig. 1), and the global city needs to actively take part in it.

Waste management and resource recovery not only prevent the adverse effects associated with waste, but also realize environmental, economic, and social benefits and help us to move one step closer to the sustainable future.

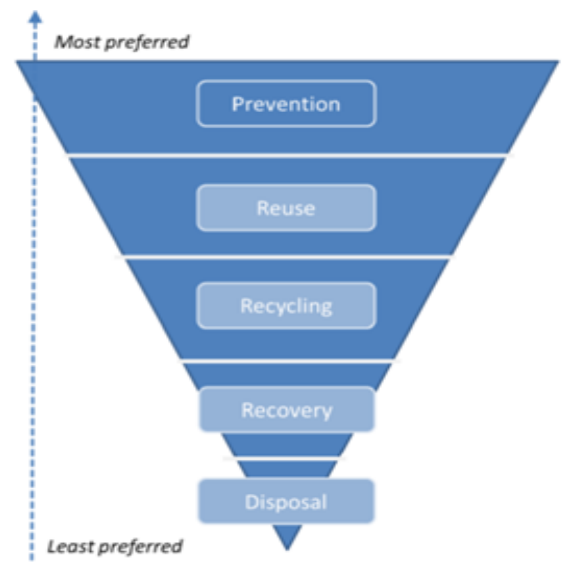

Fig. 1. Waste management hierarchy*(UNEP, 2011).

Preventing waste through efficient use of resources and raw materials is the best option. Re-using discarded goods without reprocessing or remanufacture is assumed to provide greater savings in resource consumption and is given priority over recycling.

\section{STATUS OF KOREA}

In Korea, both Nimby phenomenon and economic difficulties make it difficult to install environmental infrastructure. In the case of anaerobic digestion, it is limited to composting livestock manure, and this, too, is difficult due to negative images of its disgust. There are constant attempts for bioenergy utilization of livestock manure and agricultural by-products, but they are hard to be realized in local conditions, causing very low energy independence on bio-energy [7]. In the case of incineration, energy production utilizing municipal solid waste is common, but there is a difficulty in preparing construction site and processing the project because of siting Nimby due to financial difficulties. Currently the image as abomination facility needs improving rather than focusing only on energy utilization (see Table II).

\begin{tabular}{c|l|c}
\multicolumn{1}{c|}{ TABLE II: STATUS AND PROBLEM OF WASTE MANAGEMENT IN KOREA } \\
\hline \hline \multicolumn{1}{c|}{ Section } & \multicolumn{1}{|c}{ Status } & \multicolumn{1}{c}{ Problem } \\
\hline Anaerobic Digestion & $\begin{array}{l}\text { Merely manure } \\
\text { composting }\end{array}$ & $\begin{array}{l}\text { Difficulty of facility } \\
\text { location due to Nimby }\end{array}$ \\
\hline Incineration & $\begin{array}{l}\text { General tendency } \\
\text { utilizing energy from } \\
\text { waste }\end{array}$ & $\begin{array}{l}\text { Economic difficulties } \\
\text { of local government }\end{array}$ \\
\hline
\end{tabular}

\section{CASE STUdY}

\section{A. Anaerobic Digestion (Bio Energy)}

1) Mureck

In Mureck, an Autstrian town of a population of 1,700, bordering Slovania, an energy business was initiated by ideas of residents with an interest in energy issues. At first canola was raised in large field in its town in order to produce biodiesel for transportations such as cars and tractors with the plant oil. With fund raised by the farmers and governmental subsidies, SEEG, bio-diesel company, was established in 1989. Then it increased its biodiesel production efficiency with help of the Graz University and received consultancy Biodiesel Production International, using purified waste vegetable oil rather than rapeseed flowers.

As a result, in 2001 and 2006, Mureck was presented with 'World Energy Award' and the 'European Solar Award' by 'Euro Solar' a leading organization in field of recycling energy. And more than 6,000 people visit Mureck to learn its energy independence every year. $4.5 \%$ of the village population is working in the energy production facilities and jobs related to wasted cooking oil collection and shrubs and manure transport have been created. Carbon dioxide emissions was reduced up to $55,000 \mathrm{tCO}_{2}$. Starting from rapeseed flower oil, every energy companies established, the town's energy self-sufficiency is increased.

The European Union grants governmental aide or projects in conditions of joint study or cooperation between towns or countries; and this played important role in energy business in Mureck. SEEG adopts its business model by the shareholders, therefore, the residients of Mureck attend shareholder's meeting every 6 months for business related issues. Also four-year term for presidential election shows redents-leading community.

\section{2) Guissing}

Guissing is a community village consisting of 28 small 
village in Austria, Burgenland, bordered with Hungary. Guissing was facing the problem of unemployment and depopulation by the end of 1980s. However, the local government makes a decision to do regional energy independence through biomass energy that is available in the area in 1991.

Biomass cogeneration plant in Guissing supplies electricity and heating to 1,200 households with methane gas made by fermenting grass and corn. It also makes an effort to attract new businesses by providing them with heating energy at lower rate.

Guissing has many international institutions and laboratories such as Graz University of Technology and Bin University of Technology for various activities. In the middle of downtown, European Union and renewable energy research center are located, as well as more than 50 research institutes to study business in renewable energy technologies. As a result, the demand for renewable energy has increased, creating 1,100 new jobs over the past 10 years in the town with not more than 4,000 people.

Canola is big source of income for the city Rapeseed of $1 \mathrm{~kg}$ is equivalent to biodiesel of $360 \mathrm{~g}$. Guissing is supporting the finances by using rapeseed flowers as a raw material for bio fuel. More than 300 visit the city to look for the successful model of the city every week.

\section{3) Juehnde}

Juehnde is located 15 minutes away from the city of Göttingen, Germany. 140 households are living on forest lands of 800ha. Juehnde is known as a town of applied biotechnology. Located adjacent to the Göttingen, with aurban-rural exchanges, Juehnde had the advantage that it is possible to obtain enough biomass fuel in agriculture and mountainous. It was selected as a bioenergy village for it was possible to promote the collaborative project with a variety of organization run by residents.

As methane made by fermenting hay and manure was used as a raw material, biomass cogeneration plant was built in 2005. It was planned to produce electricity annually $5,000 \mathrm{MWh}$, the land of $1,300 \mathrm{ha}$ was cultivated to produce wheat, corn and hay for 9 farms; 6 farmers bred 400 cattle and pigs for $30 \mathrm{~m}^{3}$ manure per day, and to supply the wood $400 \mathrm{t}$ per year for additional heating in the forest of 800ha.

Bio-energy plant consists of anaerobic digestion facility, wood boilers and heat pipe. About $70 \%$ of the households are supplied the heat energy produced in the district heating system.

Juehnde project was started by Göttingen University in 1998, which various experts participated in. In 2001, bio energy town committee was founded by town representatives. It has features that accompany mandatory participation and contribution of town people with a cooperative association.

\section{B. Incineration}

\section{1) Spittelau incineration plant}

Spittelau incineration plant is located in Vienna, Austria. After the large fire in 1987, this incinerator was remodeled by applying both the new technologies and the design of a local architect, Friedensreich Hundertwasser, in 1991 (see Fig. 2). At the time of the fire in 1987, there was claim that the incinerator itself had to be moved to outskirts of the city, but then mayor's persuasion over a year that the incinerator located in central city could reduce logistics costs and provide heat and electricity for citizens made it possible to remodel the old incinerator instead of relocation.

Currently, waste heat from the incineration produces electricity, consumes for its own facility, sells the surpluses and in return reinvests in the environment. Moreover, eco-friendly image was focused on and a state-of-the-art technology was introduced to avoid dioxins and odors and public signage was installed for citizens to monitor the incineration process.

Electricity is produced in incinerator by using the heat generated in the course of processing 250,000tons of waste per year and used as incinerators' own electricity. Hot water is produced and supplied with 334,000 households of Vienna and cooling water is provided for 6,500 places like City Hall, hospitals and department stores.

Spittelau incineration plant is regarded as a good example of switching from social hate facility to the citizen friendly facility. It was designed with more investment fee than installating the incinerator facility, and was converted to a place loved by locals and emerged as a tourist destination in Vienna.

\section{2) Maishima incineration plant}

Maishima incineration plant is located in Japan Osaka coast waterfront industrial areas of the floor area $33,000 \mathrm{~m}^{2}$. It is a case of converting from hate incinerator facility into beautiful high-tech facilities in harmony with technology, ecology, art. Construction of new incinerators to replace eight existing incinerators-oudated-turned out one of Osaka attractions through benchmarking the case of Spittelau incineration plant (see Fig. 2).

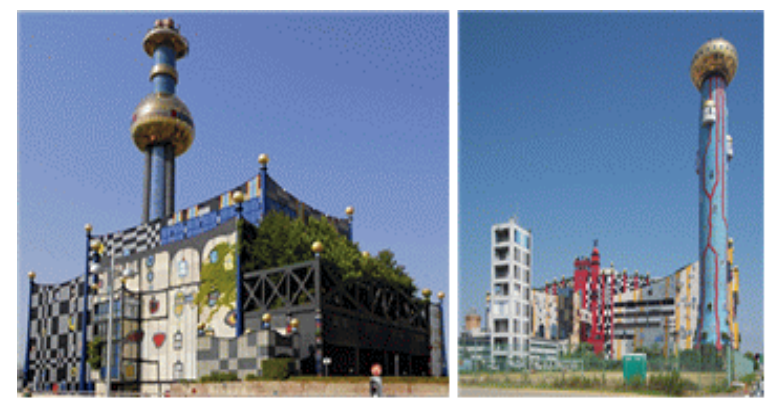

Fig. 2. Spittelau(L) and Maishima(R) incineration plant.

Environmental conservation architect, Friedensreich Hundertwasser, with a vision to build environment-friendly and beautiful facility, planned some design with internal and external stories, applying technology fundamentally. Monitoring system for incinerated waste was built with colorful looks and cavernous interior design.

This incinerator has a number of visitors from all over the world as well as native because it has their own tour system. Visitors through the educational component of the incinerator, especially students raise awareness of the litter problem and have an interest in constructing society that has no waste. First of all their effectiveness appears through visiting of more than 15,000 elementary students annually. In addition, earning financial income from electricity production and resources sales, operating electrical and lighting facilities of factory 
through electricity produced by itself, it makes a profit above annual budget through revenue from sales of remaining electricity or scrap iron recycled.

\section{Comprehensive Analysis}

The difference depending on the waste-to-energy scheme appears largely in characteristic of place and tourist resource utilization. In the case of anaerobic digestion method, trait of place is being made in village unit and in the case of incineration method it has been made in a single building, incineration facilities. In the case of tourism resources of anaerobic digestion method, visits related to driving business processes and bio-energy production appear mostly. In addition, through adding design factors incinerators play a role as tourism resources for urban landscape.

One of the common features to appear in all cases, first, is production of energy to replace fossil energy by applying state-of-the-art technology for energy recovery from waste. This contributes to coping with climate change in reducing fossil energy use as well as generating economic profit as a place producing energy. Second, high profitability and energy independence appear. Economic profit is being made through the energizing of waste resources and additional revenue is also generated from tourism resources. Third, conversion of the perception of targets-to-avoid has successfully led to residents-friendly and tourism resources. The citizen participation has taken place in the process of recognition and value conversion, which lets overcome Nimby phenomenon. From a point of view of the conversion value and awareness, the citizen participation occurs actively or passively in all cases, whereas the success of the business largely depends on the role of the government (see Table III).

\begin{tabular}{|c|c|c|}
\hline Section & Anaerobic Digestion method & Incineration method \\
\hline Difference & $\begin{array}{l}\text { - Place traits: village units } \\
\text { - Tourism Resource } \\
\text { - Utilization: Visit tour }\end{array}$ & $\begin{array}{l}\text { Place traits: Facility units } \\
\text { - Tourism Resource } \\
\text { - Utilization: Visit trip + } \\
\text { urban landscape(design } \\
\text { combines) }\end{array}$ \\
\hline Common & \multicolumn{2}{|c|}{$\begin{array}{l}\text { - Alternative energy production on applying high-tech } \\
\text { - Energy self-sufficiency and high profitability } \\
\text { - Switching perception of disgust avoided object } \\
\text { - Citizen Participation and active government role }\end{array}$} \\
\hline
\end{tabular}

\section{CONCLUSION}

As urban population increase and lifestyle changes, waste disposal problem impacting the environment and health issues, is rising in urgency. This problem is more severe toward the developing world. However, these problems can be solved by an efficient waste management, and, in particular, utilizing the residual heat and liquid ratio occurred in the waste treatment process could be used as renewable energy sources that can replace fossil energy.

The best way to overcome the Nimby is to provide economic benefits with local residents, and change their perception of the facilities into the one that they are not hazardous. In particular, the application of energy recovery from waste technology is satisfying both social, economical benefits and successful waste management; therefore, ways to efficiently introducing such practice are crucial.

Korea is also aware of the need for these potential environmental and local conditions, but constraints exist in the realization phase that follows. Local conditions and environmental practices that appear in the foreign country and the situation may be different. But perceptions and role of principals who practice it need benchmarking for its own country's situation [8]. The role of citizens and the government that are shown in case studies can be realized by our own counterparts. Efforts to narrow the differences in perception of this waste and the waste management for energy recovery from waste should be initiated. From this point of view, efficient waste management and replacing fossil energy with alternative energy can be achieved, further, urban problems such as Nimby phenomenon can be addressed, and all of this ultimately can contribute to improve climate change.

\section{REFERENCES}

[1] Copenhagen Climate Change Summit. (2009). [Online]. Available: http://www.oecd.org/fr/environnement/citiesmattertotheglobalclimate policyagenda.htm

[2] Y.-J. Jo, S. Sohn, and D. Kim, "Key indicators of the index for a green city,” Urban Design, vol. 14, no. 6, pp. 111-123, June 2013.

[3] UN. (2014). Revision of World Urbanization Prospects. [Online]. Available:

www.un.org/en/development/desa/publications/2014-revision-worldurbanization-prospects.html

[4] UNEP. (Oct. 2013). Municipal solid waste. [Online]. Available: www.unep.org/geas

[5] H. Jang, D. Lee, J. Kim, and M. Hwang, "Condition of waste treatment and waste recycling for carbon zero society," KSCE Journal of Civil Engineering, vol. 59, no. 8, pp. 55-61, Aug. 2011.

[6] Town and Country Planning Association, towards zero waste: Eco-Town waste management worksheet advice to promoters and planners, November 2013.

[7] K. So, "Conditions and strategies for bioenergy village," Bioin Special Webzine: Bioenergy, no. 11, 2009.

[8] Smart Green City Lab, Index for a green city 2014, $1^{\text {st }}$ ed., Seoul: Smbooks, 2014, ch. 4

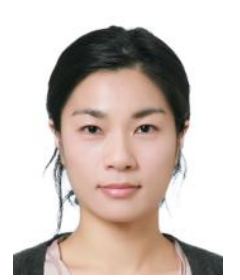

Yoojung Jo was born in Seoul in Jan. 1982. She is a candidate for the Ph.D of future city convergence engineering major at Sung Kyun Kwan University (SKKU). She is a senior researcher of Smart Green City Lab in SKKU.

Yoojung received her master's degree in 2009. After graduating, she has studied as a researcher until now. She has conducted a study on algorithm for preventive maintenance of $\mathrm{u}$-city infrastructure, index for a green city, u-city district units, and etc.

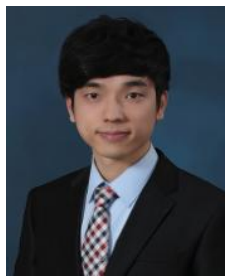

Injae Yu was born in Tokyo in June 1987. He is a student in the master's course future city convergence engineering major at Sung Kyun Kwan University (SKKU) where he is a researcher of Smart Green City Lab.

Injae has participated in some projects such as workplace and smart city, creative town, u-city plan as a researcher of Smart Green City Lab.

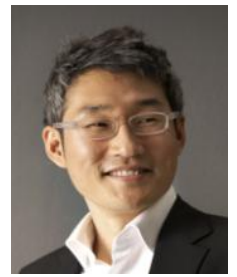

Saehyung Sohn was born in Seoul in Oct. 1969. He is a professor of architecture at Sung Kyun Kwan University (SKKU) and the UK Royal architect. After graduating from London AA School in 2000, he carried out a number of health-related projects, airport master plan and terminal design project as a senior designer on design core team of kenyang, a global green architect, in Llewelyn Davies Yeang. 
After returning to Korea in 2008, as a design director at Geonwon Architectural Firm, he fullfilled a variety of projects including residential complex facilities, airports, business facilities, government offices and B1 Block of Songdo IBD for about two years.

Since then, he has carried out carbon reduction strategies and smart urban city and U-city plan projects and served as a member of U Smart Research Committee in Korea Urban Design Institute.

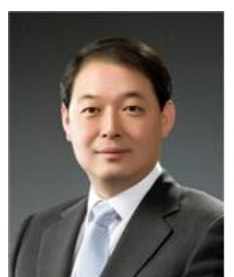

Donyun Kim is a professor of urban design at Sung Kyun Kwan University (SKKU) where he is the director of Smart Green City Lab. He is currently a commissioner of the Presidential Committee on Green Growth and a vice president of Urban Design Institute of Korea.

Donyun has been a chief planner of Seoul Digital Media City (DMC) since 1997. Currently he is also working with the Presidential Office of Korea to integrate the ideas of city-making industries and smart sustainable technologies into a paradigm of 'green growth'. This idea has the potential to support the healthy and green urbanization of Asian and African countries. In addition, he has been involved in a national research project of establishing a strategy for a low-carbon city, as the chief of the research, which includes the improvement in related legal system and the development of green city index. Donyun was also in charge of the 2012 Yeosu EXPO and New Science City master plan in Korea.

He holds a master of urban design at Pratt in New York and a Ph.D. at Seoul National University in Korea. He has been a visiting professor and research affiliate of the City Design and Development group at MIT. In 2013, Dr. Kim was awarded a medal from national government of Korea for his distinguished academic and professional contribution. 